OK 867.M94

The effect of transpiration on the absor

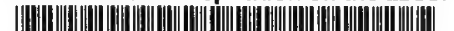

3 1924000679633 mann 


\section{Cornell University Library}

The original of this book is in the Cornell University Library.

There are no known copyright restrictions in the United States on the use of the text.

http://www.archive.org/details/cu31924000679633 



\section{The Effect of Transpiration on the Absorption of Salts by Plants}

\section{A THESIS}

Presented to the Faculty of the Graduate School of Cornell University for the Degree of DOCTOR OF PHILOSOPHY

Vol, IX, No. 6, June, rg22. 



\title{
THE EFFECT OF TRANSPIRATION ON THE ABSORP- TION OF SALTS BY PLANTS
}

\author{
WALter C. Muenscher
}

(Received for publication November 22, I92 I)

Various opinions have been offered regarding the relation between transpiration and the absorption of solutes. Those investigators who support the older theory maintain that the quantity of salts taken into a plant is directly proportional to the amount of water.transpired, and that the quantity of water transpired is in inverse ratio to the concentration of the solution. Some workers maintain that there is no direct relation between transpiration and the absorption of salts. In other words, the rate at which salts enter the cell is independentt of the rate at which water enters the cell. Others accept the theory that the water and solutes of a solution enter a plant ast independent rates, but maintain that after the solutes enter the plant they move along with the water in the "transpiration stream."

A large amount of literature has appeared dealing with transpiration and water requirements, but, with few exceptions, no papers have appeared which offer any considerable data on a possible relation between transpiration and the intake of solutes. In spite of this fact, many authors have not hesitated to employ various theories regarding the relation between transpiration and the absorption of salts in explaining results which they have obtained in investigations upon transpiration and water requirements. The fact still stands, however, that a careful search through the literature reveals no conclusive data which would substantiate the correctness of any of these theories. From a theoretical standpoint it would be reasonable to assume that the entrance of water and solutes into the plant takes place independently, since they enter not through openings which would allow for mass flow but through membranes which necessitate diffusion. Actual data presented are conflicting. The writer has been carrying on a number of experiments with reference to a possible relation between transpiration and the absorption and distribution of salts in plants. The results obtained in those experiments bearing on absorption only are reported in this paper.

\section{HISTORICAL}

Some of the earlier workers varied transpiration by increasing the supply of water or mineral nutrients and determined the effect of this change upon the dry weight and ash content of the plants: Lawes (I850) reported results obtained with several legumes and cereals grown in jars of soil treated 
with nutrient solutions. His analyses of the tops show that when transpiration was increased sometimes the amount of ash increased and sometimes it decreased. Ilienkoff (I 865) found no correlation between the quantity of water supplied and the total ash conterit of buckwheat plants the tops of which were analyzed after growing for a period of 67 days. Fittbogen (1873) found no significant difference in the quantity of ash found for a unit of water transpired by oat plants growing in soil in which the water varied from 20 to 60 percent of its water-holding capacity.

Thom and Holtz (19I7) presented data that show that in general as the concentration of the soil solution is increased the water requirement of wheat and barley plants decreases as does also the quantity of water transpired per gram of ash found in the plant. Their table at the top of page 50 shows that the ash content in the whole plants, expressed in percentage of dry weight, is about the same regardless of the concentration of the nutrient solution in which they were grown, excepting in a very high concentration which was injurious to growth.

The effect of decreased transpiration brought about by shading has been worked on first by Schloessing (1 869), and more recently by Hasselbring (I9I4 $a, b$ ). Schloessing found that a tobacco plant under a, shaded bell jar which transpired the least also possessed the smaller dry weight and ash content. Hasselbring, also working with tobacco plants, found, on the other hand, a smaller absolute amount and percentage of ash in the plants which transpired the most. The dry weight was practically the same in plants grown in the open sunlight and in the shade. He stated that it appears, therefore, that the absorption of salts by roots is independent of the absorption of water, and that the transpiration stream does not exert an accelerating effect on the entrance of salts.

Sorauer ( 1880 ) and Wollney ( $1898 a, b)$ worked on the relation of absorption of salts and transpiration as affected by atmospheric humidity. Sorauer found that pea plants growing in a dry chamber had a slightly greater dry, weight and ash content than similar plants growing in humid chambers. Wollney, working with several crop plants grown in chambers with high, medium, and low humidity, found that in general the absolute green weight and dry matter was somewhat greater in the plants grown in the more humid atmosphere. The percentage of ash and dry matter in general increased slightly with the dryness of the air. Kiesselbach (I916) found no distinct correlation between transpiration and the absolute quantity or percentage of ash or between the water requirement and ash found in corn plants grown in dry and humid greenhouses, or in different degrees of soil-moisture content. Curtis (I920) mentioned some unpublished data showing that doubling the transpiration of barley plants growing with their roots in nutrient solution has no tendency to increase salt absorption when the transpiration is increased by decreasing the atmospheric humidity.

Several authors have compared the absorption of mineral' nutrients and 
growth by plants growing in habitats where transpiration is reduced with that by plants growing in habitats where conditions for transpiration are more favorable. Among these may be cited the work of Schimper upon halophytes, and the work of Haberlandt, Burgerstein and his co-workers, and McLean upon transpiration by plants in tropical rain forests.

Schimper (I89I) pointed out that the xerophytic modifications of halophytes serve to reduce transpiration and also the absorption of salts. Although he does not say that salts enter with the water, he assumes a relation between transpiration and the absorption of salts when he states that reduced transpiration also reduces the absorption of salt and protects the plant from the danger of too much salt accumulating in the leaves. The works of Stahl (I 894) and others offer better explanations for the occurrence of xerophytic adaptations among halophytes.

Haberlandt (I892) first definitely suggested that there is no relation between transpiration and the quantity of mineral nutrients absorbed from the soil. He maintained that diffusion independently of transpiration causes the movement of salts from the roots to the highest parts of plants. Transpiration is only one factor and not the important one in the movement of salts. Haberlandt presented data to show that the rate of transpiration in tropical forests is less than in central Europe. High relative humidity in spite of high temperatures reduces the transpiration in the tropics. Not all workers agree with Haberlandt. In opposition to Haberlandt, Burgerstein (I897), Stahl (I894), and Giltay (I897) claimed that the plants in the tropical rain forests transpire more than those in a temperate region such as central Europe. It is beside the question to discuss the validity of claims made by the opponents in this controversy. It will suffice here to point out that Haberlandt, who believed that the transpiration in the tropics is not higher than in central Europe, also maintained that transpiration is not necessary for the absorption of salts; while Burgerstein and his followers, who believed that the transpiration in the tropics is very high, adhered to the theory that there is a relation between transpiration and the absorption of salts. Burgerstein said that a green plant in synthesizing large quantities of organic matter needs large quantities of inorganic nutrients, and that, since these are in a very dilute solution in the soil water, the plant must take up large amounts of this solution and transpire the excess water. Since only a small amount of this water is used in synthesis, transpiration makes it possible for a plant to conduct large quantities of water and nutrients to the assimilating tissues in a short time.

McLean (19I9) worked with plants of the tropical rain forests of Brazil. $\mathrm{He}$ found that leaves taken from the plants growing under these conditions of assumed depressed transpiration showed a higher ash content relative to the total assimilates than sun plants. This he takes to indicate that

The absorption of mineral salts is independent at least of foliar evaporation, the most complete suppression of which is thus seen to be of only secondary importance to the plant. 
Whether the suppression of foliar evaporation signifies the suppression of a water current in the axis does not appear.

The authors of several important textbooks of plant physiologySachs (I887), Pfeffer (I900), and Jost (I907) - state that a "transpiration current" is necessary for supplying adequate quantities of the necessary salts to the plant. These authors make statements to the effect that it is more or less obvious that it is necessary for a plant to take up larger amounts of a dilute solution than of a concentrated solution in order to supply the salts necessary for growth. None of these authors presents any new data nor even cites conclusive data which supports. his conclusions. It is true, as McLean (I9I9) has pointed out, that the almost complete suppression of transpiration does not necessarily signify the suppression of a water current; but in this connection it should also be borne in mind that the existence of a transpiration stream in the sense of mass movement of solution in normal growing plants has yet to be demonstrated.

This brief review of a number of works which include some data or discussions of the relation of transpiration to the absorption of salts serves to indicate that the data presented and the conclusions drawn are often contradictory. It would be surprising indeed to find a group of workers obtaining the same results and arriving at the same conclusions under such a variety of methods. It might be expected that in a study of the relation between transpiration and the absorption of salts the results might differ depending upon whether transpiration was varied by changing the atmospheric humidity, light intensity, soil water, or concentration of the nutrient solution. All these factors affect transpiration, but when one varies one of these factors in endeavoring to reduce transpiration, he may also yary some other factor or factors which may become the determining factor. Perhaps a lack of consideration of the principle of limiting factors in addition to a lack of uniform methods and materials is largely responsible for some of the contradictory results presented by various investigators.

A few early investigators presented data which seemed to them to indicate that there is a relation between transpiration and the absorption of salts; others got no definite results. Teachers and investigators were inclined to accept the former results and to disregard the latter. Even the writers of many of the physiological textbooks in use today make very definite statements regarding the relation of transpiration to the absorption of salts with nothing except the fragmentary data of some of these earlier workers and speculation upon which to base their statements. Results obtained by some of the more recent workers indicate that there is not necessarily a relation between the quantity of water transpired and the quantity of salts absorbed. Perhaps other factors besides transpiration are more important in determining how large are the quantities of salts absorbed by plants. 


\section{General OUtLine of Experiments}

The experiments which are reported in this paper were undertaken in order to obtain data which might indicate whether or not there is any relation between absorption of water and of mineral nutrients. The absorption of water was determined by measuring volumetrically the amount of water lost from the containers. The absorption of salts was determined by analyzing the plants for total ash. It is realized that the measure of ash does not represent an actual measurement of salts absorbed. However, with a uniform solution and a uniform method of analysis, for a given species the results are comparable as far as relative values are concerned. Two series of experiments, summer and winter, were conducted in the greenhouse. In the summer series the rate of transpiration was reduced by increasing atmospheric humidity and by decreasing the intensity of sunlight. In the winter series transpiration was reduced by decreasing the light intensity and also by increasing the concentration of the nutrient solution. Cultures were grown under the following conditions:

\section{Surrmer Series}

a. Dry chamber; standard Knop's solution ${ }^{1}$ (.14\%).

$b$. Humid chamber; standard Knop's solution (.14\%).

c. Sunlight; standard Knop's solution (.I4\%).

d. Shade tent; standard Knop's solution (.I4\%).

\section{Winter Series}

e. Sunlight; dilute Knop's solution (.07\%).

$f$. Shade tent; dilute Knop's solution (.07\%).

g. Sunlight; concentrated Knop's solution (.28\%).

\section{Materials and Methods Used}

\section{Summer Series}

The chambers used for the dry and humid series of cultures consisted of large glass cases each I40 centimeters long, 70 centimeters wide, and I Io centimeters high, placed in the middle of a greenhouse room. The air was kept in circulation continuously during the daytime by a fan in each chamber. Fresh air was pumped into the chambers by a compressor which was attached to a motor outside the chamber.

The atmospheric humidity in the humid chamber was kept high by a

${ }_{1}^{1}$ The following standard Knop's solution was employed as the basis for making up the nutrient solutions:

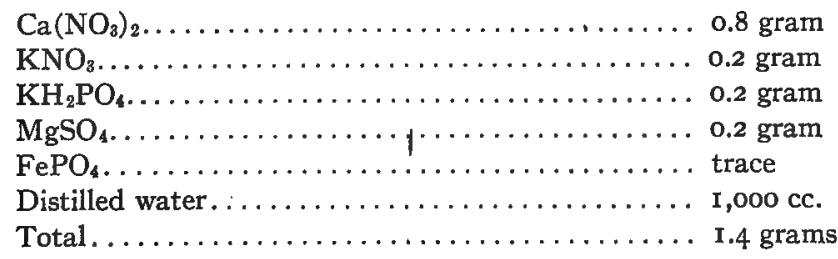


system of twelve Livingston's porous-cup atmometers which were fed from an elevated water tank. The bottom of the chamber was also covered by two large flat trays of water. Under these conditions it was possible to keep the relative humidity between 70 and roo percent. The temperature varied from $I 5^{\circ}$ to $3 \mathrm{I}^{\circ} \mathrm{C}$. during the daytime, usually averaging about $25^{\circ}$ C. The atmospheric humidity in the dry chamber was kept low by the use of anhydrous calcium chloride. Under these conditions it was possible to keep the relative humidity between 30 and 60 percent. The temperature variations in the dry chamber were about the same as in the humid chamber, but often the temperature was slightly higher in the former. The evaporating power of the air was determined by standardized Livingston's dark porous-cup atmometers. The average quantity of water lost per day for seven days was ${ }_{3} 3$ cubic centimeters in the dry chamber as compared with 6 cubic centimeters in the humid chamber.

The cultures growing in the sunlight were placed about 20 centimeters apart on a greenhouse bench. The relative humidity under these conditions varied from 25 to 60 percent. The temperature was usually between $22^{\circ}$ and $26^{\circ} \mathrm{C}$., but the extremes were $14^{\circ}$ and $30^{\circ} \mathrm{C}$. The cultures grown in the shade were on the same greenhouse bench, but were covered with a tent of the same size and shape as the dry and humid chambers, made of two layers of cheesecloth, so as to reduce the sunlight. Within this tent the relative humidity was usually about 5 percent higher than in the open sunlight. The temperature was usually from I to 5 degrees lower than in the open sunlight. The average daily evaporation from standardized atmometers was 29 cubic centimeters in the sunlight and I7 cubic centimeters in the shade.

Barley (Hordeum vulgare L.) was used in this experiment. In order to avoid as far as possible error due to individual variation, seed from a pure line of barley was obtained from the department of plant breeding, Cornell University. The seeds, selected for uniformity in size and shape, were sterilized by formalin treatment, and germinated. When the roots were about four centimeters long the seedlings were planted in culture jars. The culture jars used throughout these experiments were quart fruit jars of the "Improved Mason" brand which were covered with black paper. Four seedlings were planted in each culture jar. After standing on a greenhouse bench for one week, those cultures which contained four healthy plants were divided into four similar lots of 28 cultures and placed under the following . conditions:
a. Dry chamber
b. Humid chamber
c. Sunlight
d. Shade tent

These cultures were grown for five weeks, August 4 to September 8 , 1920. During this time the water lost by transpiration was replaced with 
distilled water every two or three days, and the solution was changed every fifth day. At the end of five weeks all cultures were taken down and the green weight, dry weight, and ash weight were determined for the tops and roots of each culture. After the dry weights had been determined, the tops and roots. were incinerated in an electric furnace to determine the total ash content. The ashing was made at a low red heat for several hours: This furnace carried a load of eight crucibles at a time. In order to reduce the error due to the method of ashing, each load consisted of one crucible containing the tops and another containing the roots of one culture from each of the four conditions under which the cultures were grown.

\section{Winter Series}

The materials and methods employed in the winter series were the same as those employed in the summer series. The plants used in this series came from the same lot of seed as was employed for the summer series. Two solutions were used, one a dilute Knop's solution (0.07 percent) and the other a concentrated Knop's solution (o.28 percent). After these cultures had remained upon the greenhouse bench for one week, all those which did not contain four healthy plants were discarded, and the rest were divided into three groups and placed under the following conditions:

e. Sunlight; dilute Knop's solution ( $0.07 \%)$

$f$. Shade tent; dilute Knop's solution (0.07\%)

g. Sunlight; concentrated Knop's solution ( $0.28 \%$ )

These cultures were grown for five weeks, from January I9 to February 24, I92 I. During this time the water lost by transpiration was replaced with distilled water every two or three days, and the solution was changed every fifth day. At the end of five weeks the cultures were all taken down, and the green weight, dry weight, and ash weight were determined for the tops and roots of each culture.

\section{Data and Discussion \\ Summer Series \\ Dry-Humid Cultures}

Table I presents a summary of the data obtained from the cultures in which transpiration was varied by changing the atmospheric humidity of the chambers in which they were grown. The plants in the humid chamber were slightly taller and their leaves were slightly longer than those in the dry chamber. The roots of the plants grown in the dry chamber were on the average about six centimeters longer and branched more profusely than those of the plants grown in the humid chamber. The total green weight. was slightly greater in the plants grown in the humid atmosphere, probably because of the greater quantity of water in their tissues. The 
total dry weight was slightly greater in the plants grown in the dry atmosphere. The total ash content was only slightly greater, I47 milligrams per culture in the plants grown in the dry atmosphere as compared with I35 milligrams per culture in the plants grown in the humid atmosphere. The total ash expressed as percentage of dry weight was only about five percent less (ratio of dry to humid $=$ Ioo : 94.7) in the plants grown in the humid chamber than in those grown in the dry chamber. The ash, expressed as percentage of green weight, was about fourteen percent less (ratio of dry to humid $=$ Ioo: 86.4) in the plants grown in the humid chamber.

TABle I. Relation of Ash Content in Barley Plants to the Amount of Transpiration as Affected by a Difference in Atmospheric Humidity. Summer Series.

Plants Grown 5 Weeks (August 4 to September 8, igzo)

\begin{tabular}{|c|c|c|c|c|c|c|}
\hline & \multicolumn{3}{|c|}{ Dry Chamber } & \multicolumn{3}{|c|}{ Humid Chamber } \\
\hline & Tops & Roots & Plants & Tops & Roots & Plants \\
\hline 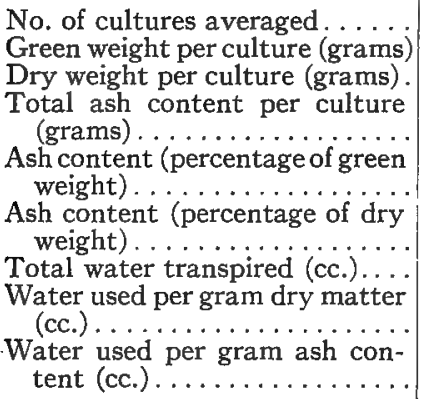 & $\begin{array}{c}6.5 \\
.60 \\
.125 \\
1.92 \\
20.7\end{array}$ & $\begin{array}{c}2.2 \\
.1 \mathrm{I} \\
.022 \\
1.00 \\
20.02\end{array}$ & $\begin{array}{c}25 \\
8.7 \\
.7 \mathrm{I} \\
. \mathrm{I} 47 \\
\mathrm{I} .69 \\
20.63 \\
350 \\
492.96 \\
2,380.95\end{array}$ & $\begin{array}{c}7.206 \\
.5854 \\
. \mathrm{I} 6 \\
\text { I.6I } \\
\text { I9.63 }\end{array}$ & $\begin{array}{c}2.067 \\
.1068 \\
.019 \\
.90 \\
. \\
18.07\end{array}$ & $\begin{array}{c}25 \\
9.270 \\
.6922 \\
.135 \\
1.46 \\
19.54 \\
170 \\
245.59 \\
\mathrm{I}, 259.25\end{array}$ \\
\hline
\end{tabular}

The data show that by increasing the atmospheric humidity the quantity of water transpired was reduced from 350 cubic centimeters to I7o cubic centimeters per culture for the period of five weeks. This reduction in transpiration also correspondingly reduced the water requirement from 492 to 245 . The quantity of water transpired per gram of ash content found in the plants was also reduced to approximately one half when transpiration was reduced. These data seem to check with those reported by Hasselbring (rgI4 a); Kiesselbach (I916), McLean (I9I9), and Curtis (1920), indicating that there is no direct relation between transpiration and the ash content in plants.

The fact that the absolute quantity or percentage of ash is reduced but slightly when transpiration is reduced to less than one half seems significant evidence against the theory that there is a direct relation between transpiration and the absorption of salts. Even the slightly greater ash content of the plants in the dry chamber seems to be determined by some factor other than the amount of water absorbed, namely food supply, which will 
be discussed later. If the salts in the solution enter the plant with the water and the entrance of the water is determined largely by the rate at which it is transpired, then, for a given concentration of salts, the greater the quantity of water transpired the greater will be the amount of salts brought in by the water absorbed. Burgerstein (I897) stated that a growing plant must take up large quantities of water to supply it with the necessary inorganic elements. Sorauer (I880) and Thom and Holtz (I9I7) suggested that the greater the concentration of the nutrient solution the smaller the quantity of it necessary to supply the plant with the necessary amounts of nutrient salts. Sachs (1887), Pfeffer (I900), and Jost (1907) implied a direct relation between transpiration and the absorption of salts. The data presented in table I do not bear out any direct relation between transpiration and the absorption of salts in barley plants grown in water cultures. On the contrary, the data indicate that the salts enter the plant independently of the rate of transpiration.

\section{Light-Shade Cultures}

Table 2 presents a summary of the data obtained from the cultures in which transpiration was reduced by shading. The shaded plants had slightly taller tops but were more slender and had fewer leaves than the plants growing in the open sunlight. The shaded plants stooled very little while the plants growing in the sunlight all stooled profusely. The roots of the shaded plants were much shorter and had fewer branches than those grown in the sunlight. The total green weight, dry weight, and ash weight were reduced to less than one half in the shaded plants. The shading not only reduced transpiration, but also reduced the photosynthetic activity of

TABLE 2. Relation of Ash Content in Barley Plants to the Amount of Transpiration as Affected by a Difference in Light Intensity. Summer Series.

Plants Grown 5 Weeks (August 4 to September 8, I920)

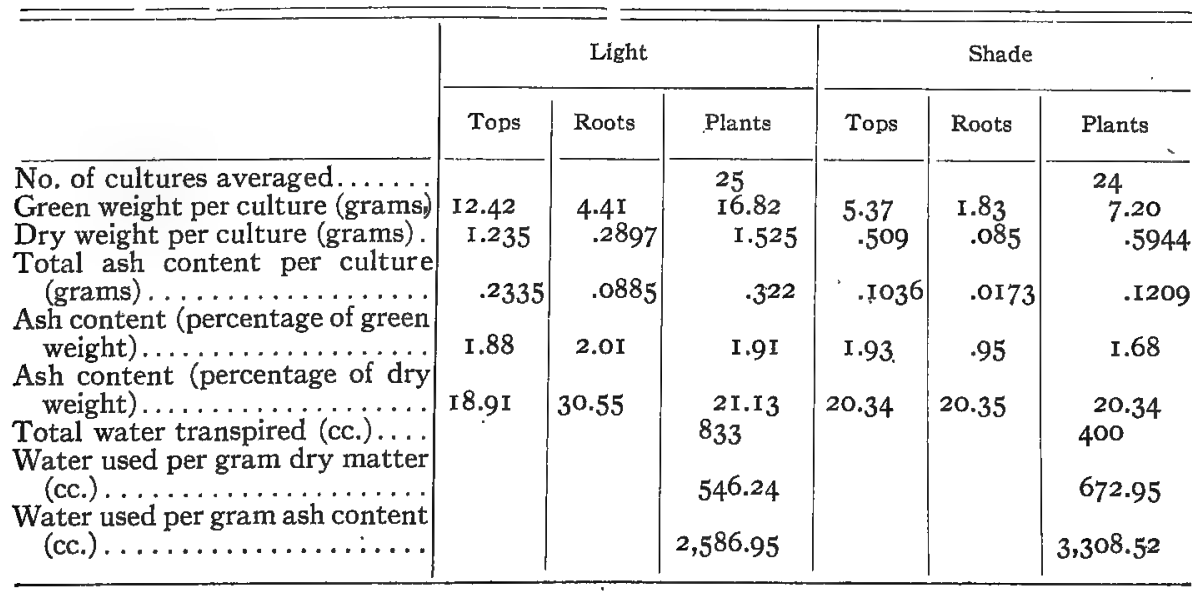


the plants. This limited the amount of food available for growth, and as a result of checked growth smaller quantities of inorganic nutrients were used. The total has expressed as percentage of dry weight was only about four percent less (ratio, light to shade $=$ roo: 96.3) in the shaded plants. Expressed as percentage of green weight the ash was about twelve percent less (ratio, light to shade $=100: 87.9$ ) in the shaded than in the unshaded plants.

The total transpiration per culture for the period of five weeks was 833 cubic centimeters in the unshaded as compared with 400 cubic centimeters in the shaded cultures. The water requirement, contrary to the common idea that this always increases under conditions favoring high transpiration, decreased from 672 in the shaded cultures to 546 in the unshaded cultures which actually transpired more than twice as much as the shaded plants. The amount of water transpired per gram of ash was considerably less in the unshaded plants than in the shaded ones. This is just the opposite of the results obtained when transpiration was doubled by decreasing the atmospheric humidity, which doubled both the water requirement and the water used per gram of ash (table I).

These data agree with those of Schloessing (I869) who found that a tobacco plant grown under a shaded bell jar had a smaller total ash content and a smaller dry weight than plants grown in the open. When the plant was shaded, not only was transpiration reduced, but the amount of available food was also limited, growth was checked, and the plant utilized smaller quantities of inorganic nutrients. Hasselbring (I9I4 a) did not find a reduction in total ash content or dry matter by shading tobacco plants. It is probable that light was not reduced enough to become a limiting factor for tobacco plants under the conditions of his experiment in Cuba. His shaded plants were much larger than those grown in the open, and perhaps the increased photosynthetic area was enough to offset any reduction in the rate of photosynthesis due to shading. In the experiment reported here light was a limiting factor.

The data presented in table 2 show that, when transpiration was reduced by shading, the total ash content was also reduced. This might lead one to infer that there exists a relation between transpiration and the absorption of salts. It must be remembered, however, that, when transpiration was reduced by shading, the photosynthetic activity was also reduced at the same time, as is shown by the fact that both green and dry weights of the shaded plants' were less than one half as great as those of the plants that were not shaded. If checking the transpiration alone were responsible for the reduced ash absorption, then the results of the dry-humid cultures presented in table I should correspond with the results of the light-shade cultures in table 2. These data show that when transpiration is reduced to one half by increasing the humidity, the total dry matter and ash were reduced only slightly and the water requirement and the water used per 
gram of ash were reduced to approximately one half (table I). When transpiration was reduced to one half by shading, the total dry matter and ash were reduced to considerably less than one half while the water requirement and the water used per gram of ash were increased considerably (table 2).

These results seem to indicate that growth, as limited by food supply, rather than the rate of transpiration, determines the rate of absorption and total absorption of salts by plants. This view is strengthened by the fact that, in these experiments, the average percentage of ash expressed in terms of dry weight in whole barley plants of the same age is about the same regardless of whether transpiration was reduced by increasing atmospheric humidity or by decreasing the light intensity by shading. Table 3 presents a summary of the percentages, with probable errors, ${ }^{2}$ of ash based upon the dry weights of tops, roots, and total plants, of the cultures grown under the various conditions in the summer series. Table 4 presents a summary of the percentages with probable errors of ash based upon green weights of the same cultures.

There is no good criterion for measuring growth under all conditions. If total green weight is used, one must consider the variation in the water content in the tissues of the plants growing under various conditions. Data presented in tables I and 2 indicate that the water content of the plants grown in the humid atmosphere or in the shade is much higher than in plants grown in a dry atmosphere or in the open sunlight. This probably explains the variation in ash content expressed as percentage of total green weight. Total dry weight seems to be a more satisfactory criterion for measuring growth in plants where large quantities of storage products are not formed. Table 3 shows a close relation between the weight of dry matter and ash content in barley plants regardless of the quantity of trans- . piration. The variation in the average percentage of ash for the cultures grown under various conditions is only about five percent of the total ash. This shows a remarkable constancy in the percentage of ash in dry weight when compared with the great variation in the quantity of water absorbed per unit of ash content of the plants under the various conditions of this experiment.

TABLE 3. Comparison of the Average Percentage of Ash Based upon the Dry Weight of Tops, Roots, and Total Plants (Averages of cultures in tables $I$ and 2)

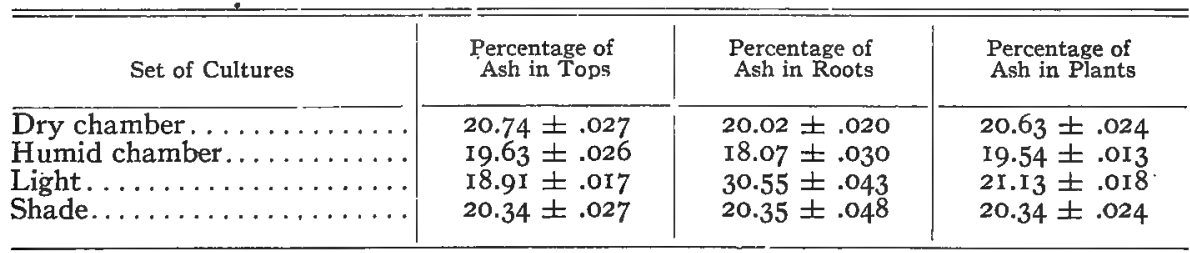

${ }^{2}$ For the calculation of probable errors Bessel's formula was used. 
TABLE 4. Comparison of the Average Percentage of Ash Based upon the Green Weight of Tops, Roots, and Total Plants (Averages of cultures in tables $I$ and 2)

\begin{tabular}{|c|c|c|c|}
\hline Set of Cultures & $\begin{array}{l}\text { Percentage of } \\
\text { Ash in Tops }\end{array}$ & $\begin{array}{l}\text { Percentage of } \\
\text { Ash in Roots }\end{array}$ & $\begin{array}{l}\text { Percentage of } \\
\text { Ash in Plants }\end{array}$ \\
\hline 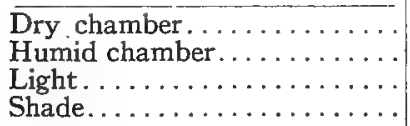 & $\begin{array}{l}1.92 \pm .030 \\
1.61 \pm .022 \\
1.88 \pm .028 \\
1.93 \pm .031\end{array}$ & $\begin{array}{r}\mathrm{I} .00 \pm .024 \\
.93 \pm .024 \\
2.01 \pm .046 \\
.95 \pm .036\end{array}$ & $\begin{array}{l}1.69 \pm .026 \\
1.46 \pm .016 \\
1.91 \pm .019 \\
1.68 \pm .026\end{array}$ \\
\hline
\end{tabular}

\section{Winter Series}

\section{Light-Shade Cultures}

A series of cultures was set up during the winter in order to check the results obtained by shading plants in the summer experiment. Table 5 presents a summary of the data obtained. The data are self-explanatory and check very closely with the light-shade cultures of the summer series. The absolute values for green weight, dry weight, and ash weight are slightly lower throughout, but relatively the results duplicate those of the summer series. The water requirement and the quantity of water used per gram of ash content were increased considerably in the plants growing in the shade under conditions of low transpiration. This relation holds not only between the shaded and unshaded plants within the summer and winter series, but also between the summer and winter series. The plants growing on an exposed greenhouse bench and in a shade tent in winter receive much less sunlight than plants growing under similar conditions in the summer.

TABle 5. Relation of Ash Content in Barley Plants to the Amount of Transpiration as Affected by a Difference in Light Intensity. Winter Series. Plants

Grown 5 Weeks (January Ig to February 24, Ig2I)

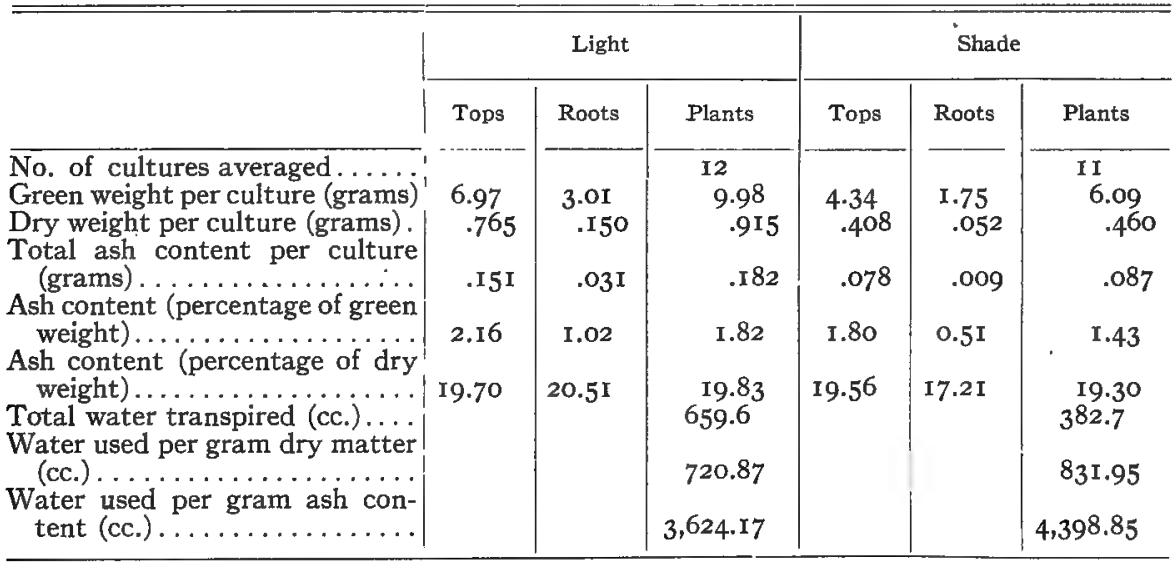

This probably explains the increase in water requirement and in quantity of water used per gram of ash content in the plants of the winter series. 
It is true that the concentration of the solution used in the winter series was only one half as great as in the summer series. The question might be raised as to whether in this case the dilute solution, rather than shading, might cause the increase in water requirement. The following experiment shows that this is not the case.

\section{Dilute-Concentrated Solution Cultures}

Table 6 compares the data of the cultures grown in a concentrated solution with similar cultures grown in a dilute soulution under the same illumination. The plants grown in a dilute solution have slightly higher actual green weight, dry weight, and ash weight than those grown in the concentrated solution. It is possible that a concentration of 0.28 percent may have been somewhat injurious to barley. The plants grown in a concentrated solution have even a slightly higher water requirement and use a greater quantity of water per gram of ash in the winter than the plants grown in a dilute solution in the summer. It appears, therefore, that the reduced sunlight rather than the reduced concentration of the solution is largely responsible for the increased water requirement in the cultures of the winter series, even if the actual transpiration is decreased considerably by shading.

TABLE 6. Relation of Ash Content in Barley Plants to the Amount of Transpiration as Affected by a Difference in Concentration of Nutrient Solution. Winter

Series. Plants Growen 5 Weeks (January I9 to February 24, I92I)

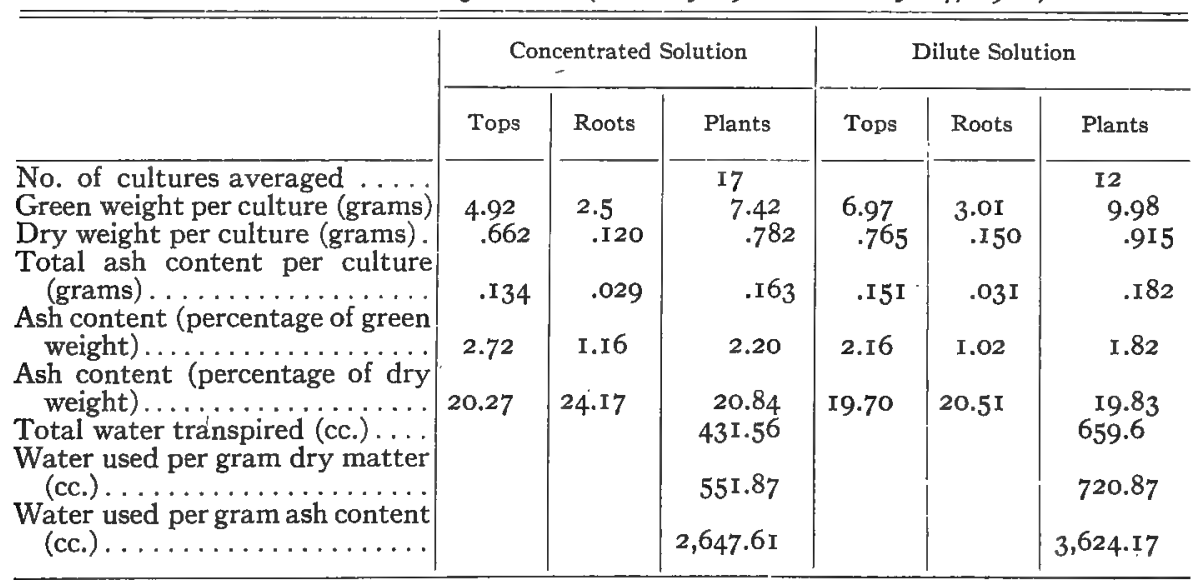

Table 7 presents the percentages of ash in the tops, roots, and total plants expressed as percentages of dry weight and green weight for all cultures grown under the various conditions of the winter series. When these data are compared with the data from the summer series in tables 3 and 4 , it will be noted that the percentage of ash expressed as percentage of dry weight usually varies less than five percent between the high and low trans- 
piring plants under the various conditions under which the plants were grown. When the ash content is expressed as percentage of green weight, the variation is from 12 to 22 percent between the high-and low-transpiring plants.

TABle 7. Comparison of the Average Percentage of Ash in Tops, Roots, and Total Plants (Averages of cultures in tables 5 and 6 )

Percentage of Ash Based upon Dry Weights

\begin{tabular}{|c|c|c|c|}
\hline Set of Cultures & $\begin{array}{l}\text { Percentage of Ash } \\
\text { in Tops }\end{array}$ & $\begin{array}{l}\text { Percentage of Ash } \\
\text { in Roots }\end{array}$ & $\begin{array}{l}\text { Percentage of Ash } \\
\text { in Plants }\end{array}$ \\
\hline $\begin{array}{l}\text { Conc. solution in light...... } \ldots \ldots \ldots \ldots \\
\text { Dilute solution in light. } \ldots \ldots \ldots \ldots \ldots \ldots \\
\text { Dilute solution in shade } \ldots \ldots \ldots \ldots \ldots \ldots\end{array}$ & $\begin{array}{l}20.27 \pm .031 \\
19.70 \pm .015 \\
19.56 \pm .035\end{array}$ & $\begin{array}{l}24.17 \pm .046 \\
20.51 \pm .026 \\
17.21 \pm .060\end{array}$ & $\begin{array}{l}20.84 \pm .028 \\
19.83 \pm .013 \\
19.30 \pm .029\end{array}$ \\
\hline
\end{tabular}

Percentage of Ash Based upon Green Weights

\begin{tabular}{|c|c|c|c|}
\hline Set of Cultures & $\begin{array}{l}\text { Percentage of Ash } \\
\text { in Tops }\end{array}$ & $\begin{array}{l}\text { Percentage of Ash } \\
\text { in Roots }\end{array}$ & $\begin{array}{l}\text { Percentage of Ash } \\
\text { in Plants }\end{array}$ \\
\hline $\begin{array}{l}\text { Conc. solution in light } \ldots \ldots \ldots \ldots \ldots \ldots \\
\text { Dilute solution in light } \ldots \ldots \ldots \ldots \ldots \ldots \ldots \\
\text { Dilute solution in shade } \ldots \ldots \ldots \ldots \ldots \ldots\end{array}$ & $\begin{array}{l}2.72 \pm .056 \\
2.16 \pm .043 \\
1.80 \pm .038\end{array}$ & $\begin{array}{l}1.16 \pm .038 \\
1.02 \pm .039 \\
0.51 \pm .019\end{array}$ & $\begin{array}{l}2.20 \pm .034 \\
\mathrm{I} .82 \pm .030 \\
1.43 \pm .033\end{array}$ \\
\hline
\end{tabular}

Those who maintain that the salts enter and move within the plant with the water might say that, under conditions of low transpiration especially, a dilute solution entering a plant is not sufficient to supply all the salts that it needs, and that therefore it absorbs additional salts from the solution in which it grows to supply its needs. On the other hand, the plant which transpires freely would absorb large quantities of solution in which are taken up all the salts needed by the plant. Under such conditions lowand high-transpiring plants might have the same ash content. Needless to say, such a teleological explanation is worthless.

Table 8 was prepared to determine whether the salts available in the solutions in which the plants were grown might limit the amounts entering the plants under any of the conditions under which the plants were grown. The first column gives the concentration of Knop's solution used. The second column gives the total water absorbed per culture. The third columin gives the total salts absorbed as determined by the ash found. ${ }^{3}$ The fourth column gives the ash equivalent of the solution, ${ }^{4}$ which indicates

${ }^{3}$ The initial ash content of the barley grains was so small that it was not subtracted from the total ash found in order to get the total ash absorbed. Four lots of Ioo uniform barley grains each were analyzed for total ash content. The following data are given in average values per single grain: Dry weight, $0.025 \mathrm{I} \mathrm{g.} \mathrm{Ash} \mathrm{weight,} 0.00067 \mathrm{~g}$. Percentage of ash, 2.68 .

"The term "ash equivalent of solution" is an arbitrary phrase here employed for designating the number of grams of total salts $\left(\mathrm{NO}_{3}\right.$ excepted) which are present in a volume of solution which is equal to the volume of water tran spired per culture. 
how much ash might have been found in the plants if the salts in the solution entered with the water in which they were in solution. These data show that in every case the quantity of salts in a volume of solution equal to the volume of water absorbed and transpired was at least as great as the quantity of ash found. In every case but one, namely, in the humid cultures of the summer series, the plants took up. more water than was necessary to supply the salts found, provided they all entered with the solution.

TABLE 8. Comparison of the Average Quantity of Water Transpired with the Average Ash Content per Culture under Various Conditions

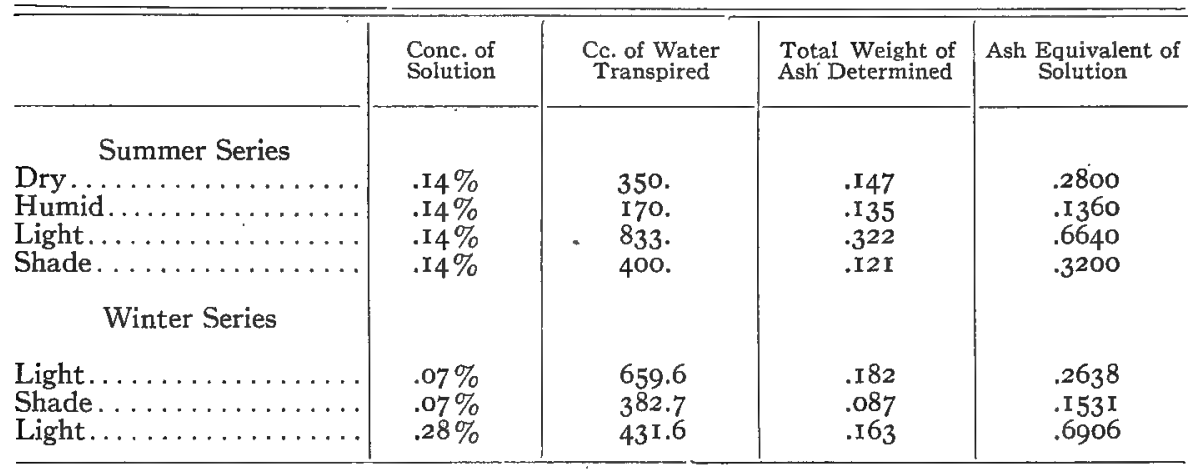

An examination of the data presented in the above tables shows that the relation between transpiration and the absorption of salts as determined under the conditions of these experiments varies with the method by which transpiration is changed. If there is a definite relation between the quantity of water transpired and the quantity of salts absorbed, one would expect that doubling the transpiration in plants would considerably increase the absolute weight and percentage of ash in plants. This is not the case.

An examination of the data of dry weights, ash weights, and ash content expressed as percentages of dry weights presented in tables I, 2, and 5 shows that in general an increase in dry weight is accompanied by a relatively greater increase in the ash weight. These data are brought together for comparison in table 9. In the dry-humid cultures the slightly lower dry weight of the tops, roots, and total plants of the cultures grown in the humid chamber is in every case accompanied by a slight decrease not only in absolute quantity but also in the percentage of ash. This same relation between increase in dry weight and ash is found between the lightshade cultures of the winter series. In the light-shade cultures of the summer series a pronounced increase in the dry weight of the tops is also accompanied by an increase in total ash weight, but the 'percentage of ash is decreased from 20.34 to 18.91 percent. The percentage of ash in the roots is increased from 20.35 to 30.55 percent when the total dry weight and ash are increased. This increase in the percentage of ash in the roots was more than enough to balance the decrease in the tops, so that the per- 
centage of ash in the whole plants was still slightly greater in the plants having the greater dry weight.

This slightly greater relative increase in the ash weight than in the dry weight seems to indicate that when a slightly greater quantity of food is available it is used for additional growth, perhaps largely in building up additional protoplasm. The addition of protoplasm, which is relatively higher in salts than non-protoplasmic structures, might increase the per-

TABLE 9. Relation between the Increase in Dry Weight and Ash in Barley Plants

\begin{tabular}{|c|c|c|c|c|c|c|c|c|}
\hline \multirow[b]{3}{*}{$\begin{array}{l}\text { Dry-Humid... } \\
\text { Summer Series } \\
\text { (From table } \\
\text { I) ...... }\end{array}$} & \multirow[b]{3}{*}{$\begin{array}{l}\text { Tops. } \\
\text { Roots. } \\
\text { Plants. }\end{array}$} & \multicolumn{2}{|c|}{$\begin{array}{l}\text { Dry Weight } \\
\text { in Grams }\end{array}$} & \multicolumn{2}{|c|}{$\begin{array}{l}\text { Ash Weight } \\
\text { in Grams }\end{array}$} & \multicolumn{2}{|c|}{ Percentage of Ash } & \multirow[t]{2}{*}{$\begin{array}{l}\text { Difference in } \\
\text { Percentage of Ash }\end{array}$} \\
\hline & & Dry & Humid & Dry & Humid & Dry & Humid & \\
\hline & & $\begin{array}{l}.60 \\
. \mathrm{II} \\
.7 \mathrm{I}\end{array}$ & $\begin{array}{l}.5854 \\
.1068 \\
\\
.6922\end{array}$ & $\begin{array}{r}.125 \\
.022 \\
.147\end{array}$ & $\begin{array}{l}.116 \\
.019 \\
.135\end{array}$ & $\begin{array}{l}20.74 \\
20.02 \\
20.63\end{array}$ & $\begin{array}{l}19.63 \\
18.07 \\
19.54\end{array}$ & $\begin{array}{l}\text { I. I I } \pm .037 \\
\text { I.95 } \pm .035 \\
\text { I.09 } \pm .027\end{array}$ \\
\hline & & Light & Shade & Light & Shade & Light & Shade & \\
\hline $\begin{array}{l}\text { Light-Shade. } \\
\text { Summer Series } \\
\text { (From table } \\
2 \text { )....... }\end{array}$ & $\begin{array}{l}\text { Tops.. } \\
\text { Roots. } \\
\text { Plants. }\end{array}$ & $\begin{array}{l}\mathrm{I} .235 \\
.2897 \\
\mathrm{I} .525\end{array}$ & $\begin{array}{l}.509 \\
.085 \\
.594\end{array}$ & $\begin{array}{l}.2335 \\
.0885 \\
.322\end{array}$ & $\begin{array}{l}.1036 \\
.0173 \\
.1209\end{array}$ & $\begin{array}{l}\text { I } 8.91 \\
30.55 \\
21.13\end{array}$ & $\begin{array}{l}20.34 \\
20.35 \\
20.34\end{array}$ & $\begin{array}{r}-\mathrm{I} .43 \pm .032 \\
10.20 \pm .064 \\
.79 \pm .029\end{array}$ \\
\hline & & Light & Shade & Light & Shade & Light & Shade & \\
\hline $\begin{array}{l}\text { Light-Shade. } \\
\text { Winter Series. } \\
\text { (From table } \\
\mathbf{5}) \ldots \ldots\end{array}$ & $\begin{array}{l}\text { Tops. . } \\
\text { Roots. } \\
\text { Plants. }\end{array}$ & $\begin{array}{l}.765 \\
.150 \\
.915\end{array}$ & $\begin{array}{l}.408 \\
.052 \\
.460\end{array}$ & $\begin{array}{l}. \mathrm{I} 5 \mathrm{I} \\
.03 \mathrm{I} \\
. \mathrm{I} 82\end{array}$ & $\begin{array}{l}.078 \\
.009 \\
.087\end{array}$ & $\begin{array}{l}\text { I9.70 } \\
20.51 \\
\text { I9.83 }\end{array}$ & $\begin{array}{l}19.56 \\
17.21 \\
\\
19.30\end{array}$ & $\begin{array}{r}.14 \pm .034 \\
3.30 \pm .053 \\
.53 \pm .031\end{array}$ \\
\hline
\end{tabular}

centage of ash slightly. If, on the other hand, food is produced in excess, as was evidently the case in the tops of the plants grown in the sunlight, a point is soon reached at which the utilization of foods and inorganic salts in the building of protoplasm is limited. The surplus food may then be used in the building of cell-wall material, or it may be stored in some other form. Since cell walls and storage products in plants are usually low in ash content, it is evident that any great increase in the production of these over the production of protoplasm would lower the percentage of ash in the dry matter.

The last column of table 9 presents the differences in the percentages of ash in the tops, roots, and total plants between the high- and low-transpiring plants. In every case the relative increase of ash was higher in the roots than in the tops. Those roots showing the greatest relative increase in ash content are those which also show the greatest increase in dry matter. 
This indicates a possible relation between the food supplied by the tops to the roots and the utilization of inorganic salts in root growth. The plants which were not shaded and had a greater food supply also had a relatively greater ash content in their roots. Table to presents the ratio of roots to tops for all cultures. The root-top ratio of dry weights increases in both

TABLE 10. Ratio of Roots to Tops under all Conditions under which Cultures were Grown $\frac{\mathrm{Td}}{\mathrm{Rd}}=\frac{\text { Dry weight of tops }}{\text { Dry weight of roots }} \quad \frac{\mathrm{Tg}}{\mathrm{Rg}}=\frac{\text { Green weight of tops }}{\text { Green weight of roots }}$

\begin{tabular}{|c|c|c|c|}
\hline \multicolumn{2}{|c|}{ Summer Series } & $\frac{T d}{R d}$ & $\frac{\mathrm{Tg}}{\mathrm{Rg}}$ \\
\hline 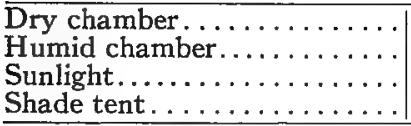 & $\begin{array}{l}\text { (0.14\% solution) } \\
\text { (o.I4\% solution) } \\
\text { (o.14\% solution) } \\
\text { (0.14\% solution) }\end{array}$ & $\begin{array}{l}5.4 \\
5.5 \\
4.2 \\
6.0\end{array}$ & $\begin{array}{l}2.9 \\
3.5 \\
2.8 \\
2.9\end{array}$ \\
\hline \multicolumn{4}{|c|}{ Winter Series } \\
\hline $\begin{array}{l}\text { Sunlight....... } \ldots \ldots \ldots \ldots \ldots \ldots \\
\text { Shade tent } \ldots \ldots \ldots \ldots \ldots \ldots \ldots \\
\text { Sunlight..... } \ldots \ldots \ldots \ldots \ldots\end{array}$ & $\begin{array}{l}\text { (0.07\% solution) } \\
(0.07 \% \text { solution }) \\
\text { (0.28\% solution) }\end{array}$ & $\begin{array}{l}5.1 \\
7.8 \\
5.5\end{array}$ & $\begin{array}{l}2.3 \\
2.4 \\
1.9\end{array}$ \\
\hline
\end{tabular}

series of the light-shade cultures where the food supply is increased by increased photosynthetic activity.

If only one of the two above-described series of cultures were used, and the results obtained were attributed to only one factor, namely, a variation in transpiration, one might conclude either that there is a relation between transpiration and the quantity of salts absorbed or that there is not, depending upon which series of cultures one happened to choose. As a matter of fact, when transpiration was reduced by shading, the photosynthetic activity of the leaves was also reduced, thus reducing the food available for growth. With a reduction in growth, smaller quantities of mineral nutrients are used and therefore inward diffusion is slower. This probably accounts for the greater difference in absolute ash content between the plants grown in the sun and in the shade as compared with the slight difference between the plants grown in the dry and humid chambers. The fact that the percentage of ash, based upon dry weight of the whole plants, varies but slightly in the plants grown in dry or humid atmosphere or in light or shade bears out the indication that in these cultures there is a relation between growth and the absorption of essential salts, regardless of the rate of transpiration.

\section{SUMMARY}

I. All plants used in the experiments reported in this paper came from a pure line of barley. The cultures were grown for five weeks in Knop's solution in quart jars under conditions of high and low transpiration.

2. The transpiration rate was reduced by (I) increasing the atmospheric humidity, (2) reducing the light intensity, (3) increasing the concentration of the nutrient solution. 
3. The absolute weight of green material, dry tnatter, and ash was determined for the tops, roots, and total plants in each culture. The ash content was expressed in percentage of green weight and dry weight.

4. The effects of reduced transpiration upon the total ash content of the plants used in these experiments depended upon how transpiration was reduced.

5. Under the conditions of these experiments, with a uniform concentration of nutrient solution, the total ash content of barley plants varied but slightly even though the quantity of water transpired was reduced to less than one half by increasing the atmospheric humidity. On the other hand, in plants in which the transpiration was reduced to less than one half by shading and the photosynthetic activity was also reduced, thus reducing the available food, the total ash content was also correspondingly reduced. When the total transpiration was reduced by increasing the concentration of the nutrient solution, the total ash content was only slightly reduced.

6. The ash content expressed in percentage of total dry weight of the whole plants varied but slightly, regardless of whether the plants were grown under conditions of high or of low transpiration and irrespective of how transpiration was reduced.

7. These results do not support the theory that transpiration has an important rôle in supplying plants with nutrient salts. The results of this investigation seem to indicate that, there being no other limiting factor, the amount of food available which would allow for growth, in which process nutrient salts are used, is an important factor in determining in how large quantities or how rapidly the essential salts enter the plant. Analyses for ash content indicate that there is little or no relation between transpiration and the absorption of salts in barley plants.

This investigation was suggested by and conducted under the direction of Professor O. F. Curtis, to whom the writer is indebted for helpful advice and a constant interest shown throughout its progress.

Laboratory of Plant Physiology, CORNELL, UNIVERSITY

\section{LITERATURE CITED}

Burgerstein, A. Ueber die Transpirationsgrösse von Pfanzen feuchter Tropengebiete. Ber. Deutsch. Bot. Ges. I5 : I54-165. I897.

/Curtis, O. F. The upward translocation of foods in woody plants I. Tissues concerned in translocation. Amer. Jour. Bot. $7:$ IOI-124. 1920.

Fittbogen, J. Untersuchungen über das für eine normale Production der Haferpflanze notwendige Minimum von Bodenfeuchtigkeit sowie über die Aufnahme von Bestandteilen des Bodens bei verschiedenen Wassergehalt desselben. Landw. Jahrb. 2 : 252-371. 1873 .

Giltay, E. Vergleichende Studien über die Stärke der Transpiration in den Tropen und in mitteleuropäischen Klime. Jahrb. Wiss. Bot. $30: 6$ 5 $_{5} 644$. 1897 . 
Haberlandt, G. Anatomisch-physiologische Untersuchungen über das tropische Laubblatt. Sitzungsber. Akad. Wiss. Wien (Math.-Naturw. KI.) I, ror : 785-816. I 892.

- Ueber die Grösse der Transpiration im feuchten Tropenklima. Jahrb. Wiss. Bot. 3I : 273-288. I 897 .

Hasselbring, $\mathbf{H}$. Relation between the transpiration stream and absorption of salts. Bot. Gaz. $57: 72,73$. I9I4 $a$.

- The effect of shading on transpiration and assimilation of the tobacco plant in Cuba. Bot. Gaz. $57: 257-286$. I9I4 $b$.

Ilienkoff, P. A. Einige Versuche zur Bestimmung des Einflusses welchen die Bodenfeuchtigkeit auf die Vegetation ausübt. Ann. Chem. Pharm. I36 : 160-165. r865.

Jost, L. Lectures on plant physiology (English ed.). Pp. 564. Oxford, 1907.

Kiesselbach, T. A. Transpiration as a factor in crop production. Nebr. Agr. Exp. Sta. Res. Bull. 6. Pp. 2r4. I9r6.

Lawes, J. B. Experimental investigation into the amount of water given off by plants during their growth; especially in relation to the fixation and source of their various constituents. Jour. Hort. Soc. London $5: 38-63$. I 850 .

McLean, R. C. Studies in the ecology of tropical rain-forest: with special reference to the forests of South Brazil. Jour. Ecol. $7: 5-54 ;$ I2I-172. í919.

Pfeffer, W. Plant physiology (English ed.), vol. I. Pp. 632 . I900.

Sachs, J. Lectures on the physiology of plants (English ed.). Pp. 836. $\quad$ I887.

Schimper, A. F. W. Die indomalayische Strandflora. Bot. Mitth. aus den Tropen $3: 9-$ 3o. $\mathrm{I} 89 \mathrm{~T}$.

Schloessing, T. Tabac sous cloche et a l'air libre. Ann. Sci. Nat. Bot. V, Io : 366369. I869.

Sorauer, P. Studien über Verdunstung. Agr. Physik $3: 35 \mathrm{I}-490$. I880.

Stahl, E. Einige Versuche über Transpiration und Assimilation. Bot. Zeit. 52 : Ir7I46. I 894 .

Thom, C. C., and Holtz, H. F. Factors influencing the water requirements of plants. Wash. Agr. Exp. Sta. Bull. I46. Pp.64. 1917.

Wollney, W. Einfluss der Luftfeuchtigkeit auf das Wachstum der Pflanzen. Inaug. Diss. Pp. 43. Halle, 1898 a.

- Untersuchungen über den Einfluss der Luftfeuchtigkeit auf das Wachstum. Bot. Centralbl. $76: 249$. $\quad 1898 b$. 








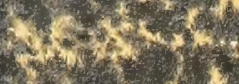

cemest

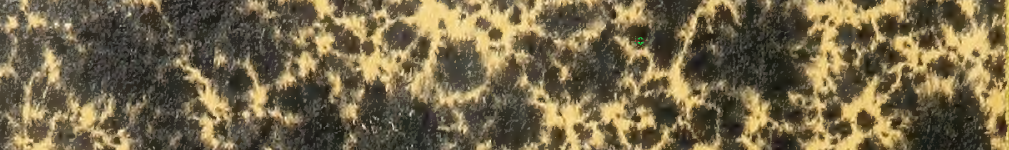

(6)

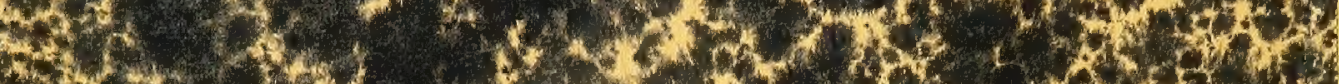

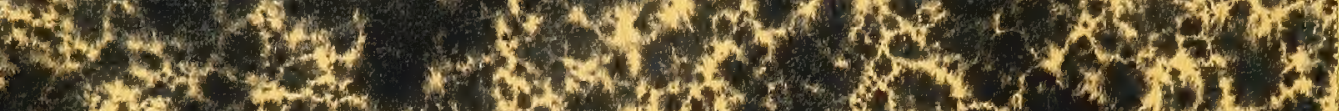

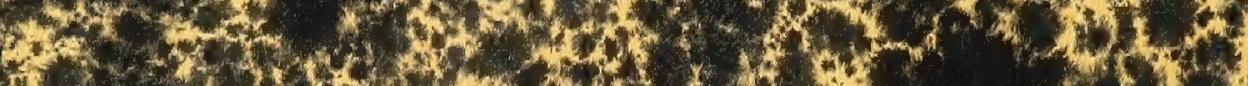

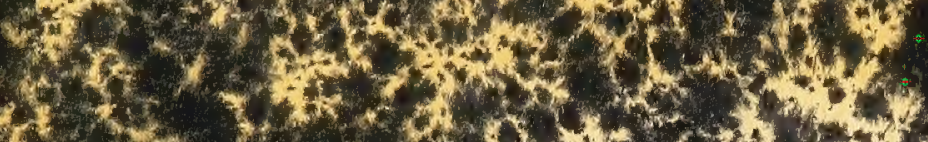

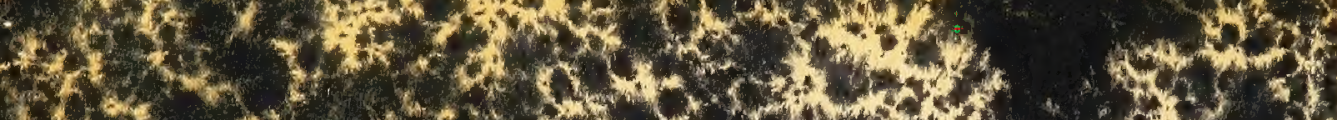

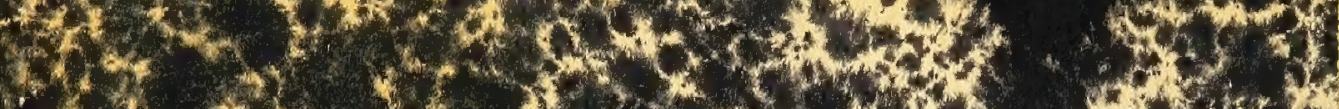

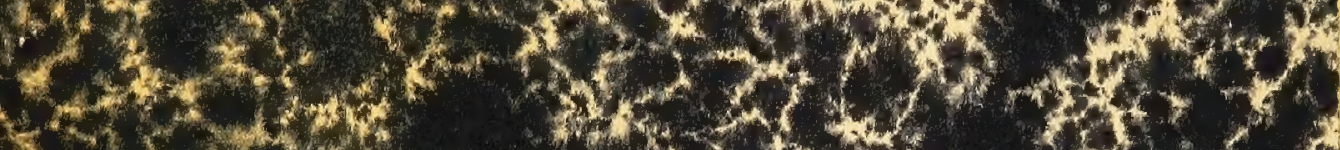

\section{1.}

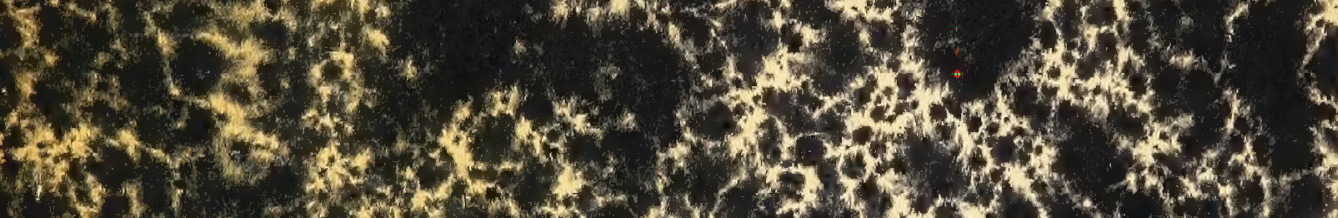

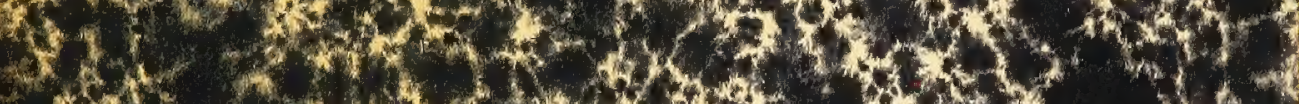
(2)

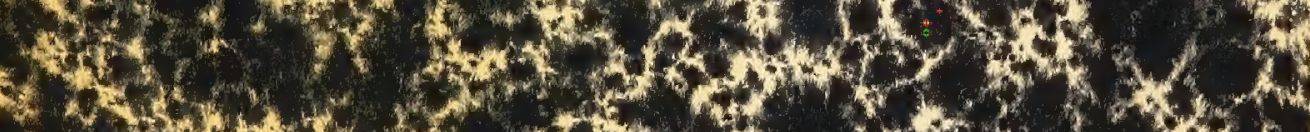

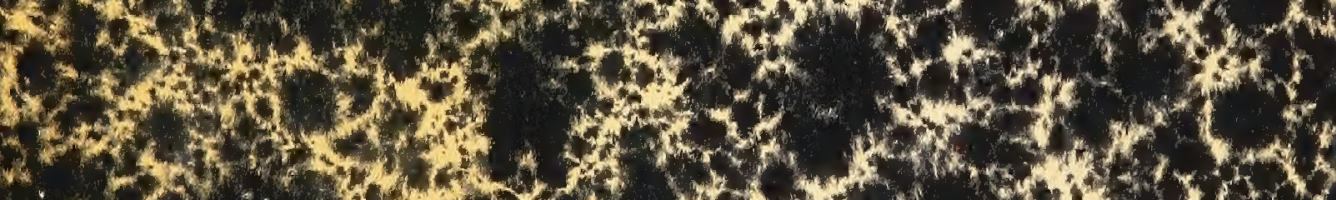
2.

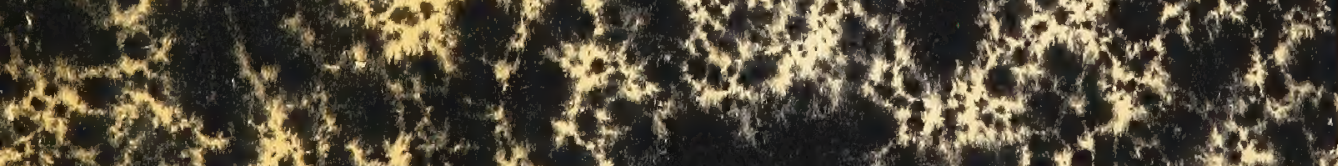

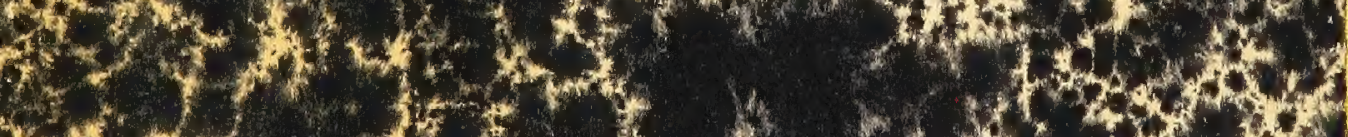

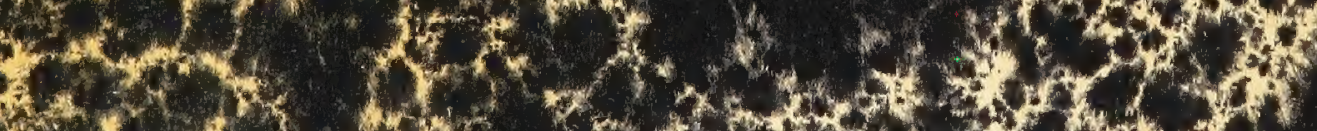

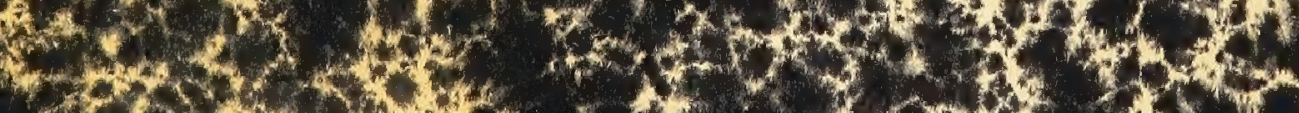

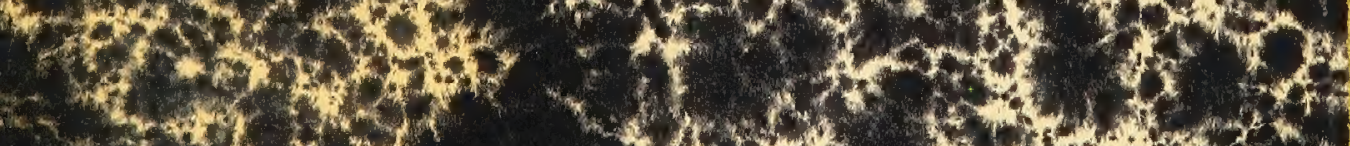

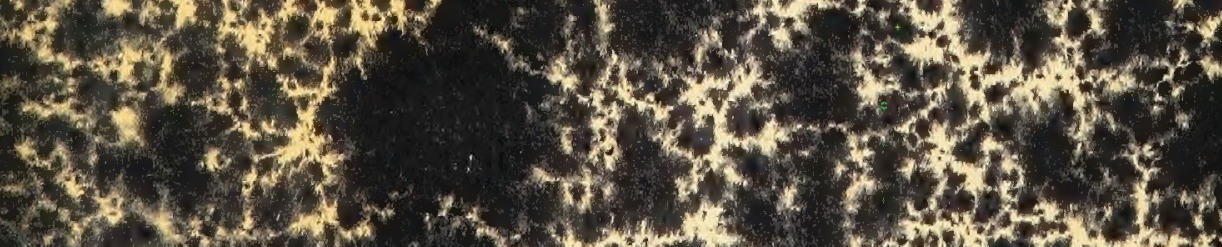
dran

at

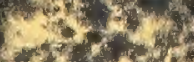

$8+2, x^{2}$

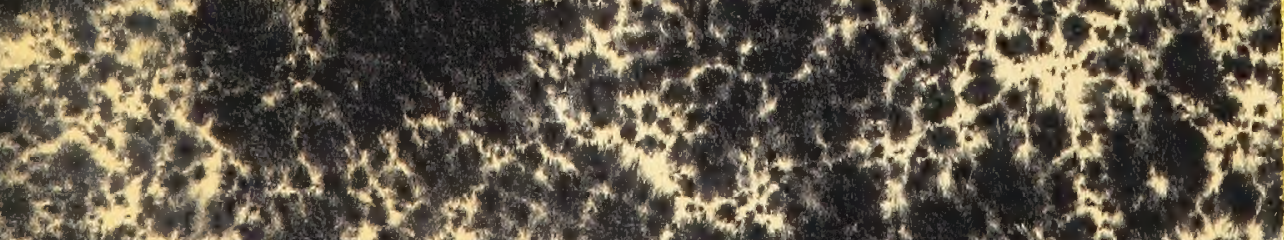
(7) 